

Tre av forfatterne: Asgeir S. Jakola, Geirmund Unsgård og Ole Solheim. Foto Ole K. Losvik
Ordforklaringer

Diffuse lavgradige gliomer: Astrocytom, oligodendrogliom og oligoastrocytom, alle WHO-grad II (av IV).

\title{
Tidlig operasjon bedrer overlevelse ved gliom
}

De fleste pasienter med lavgradige gliomer bør tilbys tidlig kirurgisk reseksjon, ifølge ny norsk studie.

Kirurgisk håndtering av pasienter med diffuse lavgradige gliomer er en av de store kontroversene innen nevroonkologien. Pasientene har ofte lite plager initialt og kan leve lenge, både med og uten behandling. I fravær av gode sammenliknende studier, er det verden over store sprik i kirurgiske behandlingsstrategier. Noen anbefaler tidlig kirurgisk behandling, mens andre anbefaler en mer konservativ håndtering.

Norske forskere har nylig gjennomført en populasjonsbasert, sammenliknende studie mellom to grupper pasienter hvor man hadde valgt ulike behandlingsstrategier (1). I den ene gruppen fikk flertallet av pasientene kirurgisk behandling, der man på et tidlig stadium forsøkte å fjerne så mye som mulig av svulsten. De fleste pasientene i den andre gruppen gjennomgikk kirurgisk biopsitaking og ble fulgt ubehandlet med MR-kontroller inntil det ble påvist vekst av tumor.

Gruppen der de fleste gjennomgikk tidlig kirurgisk reseksjon, levde signifikant lenger enn gruppen der de fleste initialt kun ble biopsert. Den absolutte forskjellen i 5 -årsoverlevelse var $14 \%$.

- Denne studien er unik i verdenssammenheng, sier førsteforfatter Asgeir S. Jakola ved Nevrokirurgisk avdeling, St. Olavs hospital. Studien viser at tidlig tumorreseksjon bør vurderes hos de fleste pasienter med lavgradige gliomer. Moderne nevrokirurgisk behandling med bruk av for eksempel intraoperativ avbildning har muliggjort tidlig kirurgisk intervensjon i større omfang enn tidligere. Ettersom det ikke var noen forskjeller i komplikasjoner mellom gruppene, er trolig en slik aggressiv behandling, med bruk av for eksempel intraoperativ 3D-ultralyd, relativt trygt.

- Med denne studien har vi bidratt med ny og viktig kunnskap innenfor nevroonkologien. Vi tror at studien kan resultere i en mer homogen og en aggressiv behandlingskultur for pasienter med lavgradige gliomer verden over, sier Jakola.

\section{Forskergruppen}

Studien er et helnorsk samarbeidsprosjekt, som har vært ledet fra Nevrokirurgisk avdeling, St. Olavs hospital. Trondheimsmiljøet ved Asgeir S. Jakola, Geirmund Unsgård og Ole Solheim er tilknyttet kompetansesenteret for ultralyd og bildeveiledet behandling, og gruppen driver med både teknologisk og klinisk hjernesvulstforskning. Fra Tromsø har Roar Kloster, som har hjernesvulster og nevrovaskulære sykdommer som sin primære forskningsinteresse, bidratt til prosjektet. De respektive patologiske avdelingene representert ved Kristin S. Myrmel, Sigurd Lindal (Tromsø) og Sverre H. Torp (Trondheim) har også bidratt.

\section{Erlend Hem}

erlend.hem@medisin.uio.no

Tidsskriftet

\section{Litteratur}

1. Jakola AS, Myrmel KS, Kloster R et al. Comparison of a strategy favoring early surgical resection vs a strategy favoring watchful waiting in low-grade gliomas. JAMA 2012; e-publisert 25.10.2012.



Artikkelen ble e-publisert 25.10. 2012 i JAMA (www.jama.com), som regnes som en av de «fem store» innen medisinsk publisering ved siden av New England Journal of Medicine, BMJ, Annals of Internal Medicine og The Lancet 